\title{
EFEKTIVITAS SHALAT TAHAJUD DALAM MENGURANGI TINGKAT STRES SANTRI
}

\section{THE EFFECTIVENESS OF PRAYING TAHAJUD TO REDUCE STRESS LEVEL AMONG STUDENTS}

\author{
Sabiq M. Azam \\ Zaenal Abidin \\ Fakultas Psikologi Universitas Diponegoro Semarang \\ Email: ego.nomura@gmail.com, zaenal_psi@yahoo.com
}

\begin{abstract}
This study aims to determine the effectiveness of praying tahajud in reducing stress pupils of "Y" Islamic Boarding School Bekasi West Java. This study is a non-randomized experimental pretest-posttest control group design. There are two research hypothesis, the first existing is individual differences in stress levels prayer group and non perform praying tahajud group, and the second hypothesis is that there are individual differences in stress levels of praying tahajud performer before and after praying tahajud, performer praying tahajud has lower stress than before performing praying tahajud. The research sample of 30 students, which consisted of 15 students in the experimental group and 15 students in the control group. Data were collected using a scale of psychology which consists of two aspects: biological and psychological. The results of the stress test of the validity of the scale there are 44 valid item $(\alpha=0.953)$, and analyzed using paired test and independent sample test. Posttest results between groups of experimentation and control group obtained $t$ count equal to -5.042 with $p$ equal to $0.000(p<0.05)$, which means that the level of students stress with performer praying tahajud group lower than the non-performer praying tahajud group. The results of pretest and posttest experimental group obtained $t$ value of 10.821 with $p$ equal to 0.000 ( $p$ $<0.05)$, which means there is a decrease in the level of individual stress after praying tahajud compared with before praying tahajud. So praying tahajud effective to reduce the stress level of pupils of "Y" Islamic Boarding School pupils aat Bekasi West Java.
\end{abstract}

Keywords: Praying Tahajud, Stress, Pupils

\section{ABSTRAK}

Penelitian ini bertujuan untuk mengetahui efektivitas shalat tahajud dalam menurunkan stres Santri Pondok Islam "Y" Bekasi Jawa Barat. Penelitian ini merupakan penelitian eksperimen pretest posttest control group design. Hipotesis penelitian ada 2, yang pertama ada penurunan tingkat stres individu setelah melakukan shalat tahajud dibandingkan dengan sebelum melakukan shalat tahajud, dan hipotesis kedua adalah tingkat stres santri yang melakukan shalat shalat tahajud lebih rendah dibandingkan dengan yang tidak melakukan shalat tahajud. Sampel penelitian ini sebanyak 30 santri, yang terdiri atas 15 santri pada kelompok eksperimen dan 15 santri pada kelompok kontrol. Metode penggalian data dengan menggunakan satu skala psikologi yang terdiri atas 2 aspek yaitu biologis dan psikologis. Hasil uji validitas pada skala stres terdapat 44 aitem valid $(\alpha=0,953)$, dan analisis data menggunakan paired t test dan independent sample test. Hasil prates dan pascates kelompok eksperimen didapatkan nilai t hitung sebesar 10,821 dengan p sebesar 0,000 $(p<0,05)$, yang berarti ada penurunan tingkat stres individu setelah melakukan shalat tahajud dibandingkan dengan sebelum melakukan shalat tahajud. Hasil pengujian pascates antara kelompok eskperimen dan kelompok kontrol didapatkan t hitung sebesar -5,042 dengan $p$ sebesar 0,000 $(p<0,05)$. Hal ini berarti 
tingkat stres santri yang melakukan shalat shalat tahajud lebih rendah dibandingkan dengan yang tidak melakukan shalat tahajud. Jadi shalat tahajud terbukti sangat efektif dapat mengurangi tingkat stres santri di Pondok Islam "Y" Bekasi Jawa Barat.

Kata Kunci : Shalat Tahajud, Stres, Santri

Pada umumnya, setiap individu pernah mengalami perasaan tertekan atau mengalami ketegangan yang dikenal dengan istilah stres. Stres merupakan bagian dari kehidupan manusia. Manusia tidak akan pernah luput dari pengalaman merasakan ketegangan dalam hidupnya. Stres muncul sejalan dengan peristiwa dan perjalanan kehidupan yang dilalui oleh individu dan terjadinya tidak dapat dihindari sepenuhnya (Sukadiyanto, 2010). Hal senada juga disebutkan oleh Hasan (2008) yang menyatakan bahwa tidak ada seorang pun yang tidak mengalami stres, dan stres merupakan gejala penyakit terbesar di abad modern. Pada umumnya, individu yang mengalami stres akan terganggu siklus kehidupannya dan merasakan ketidaknyamanan (Sukadiyanto, 2010).

Menurut Hasan (2008), stres dapat menyebabkan kerusakan fungsi fisiologis dan psikologis. Fungsi fisiologis seperti nyeri lambung, arthritis, asma dan sakit kepala. Fungsi psikologis khususnya emosi negatif yang kronik seperti kemarahan, permusuhan, depresi, kecemasan, dan agresivitas. Individu yang mengalami stres diiringi meningkatnya kecemasan dan rasa marah, selalu mengeluh, tidak sabar, dan selalu berpikiran negatif kepada halhal yang terjadi di sekitar individu (Baron \& Byrne, 2010). Individu yang mengalami stres berkepanjangan dapat memberikan dampak negatif bagi hubungan sosial dan pekerjaan sehingga produktivitas pun menurun.

Berdasarkan hasil wawancara pada tanggal 10 Januari 2014 kepada delapan subjek di Pondok Islam Pesanstren " $Y$ " Cibarusa Cikarang diketahui bahwa faktor utama penyebab stres di kalangan remaja adalah perceraian kedua orang tua yang kemudian menyebabkan remaja jatuh ke dalam pergaulan negatif seperti mengkonsumsi narkoba. Selanjutnya stres yang terjadi di kalangan orang dewasa disebabkan oleh ketidakharmonisan hubungan dengan pasangan hidup, seperti ditinggal pasangan selingkuh, perpisahan dalam perkawinan, dan ditinggal mati pasangan. Penelitian ini mengambil subjek Santri di Pondok " $Y$ " Cibarusa Cikarang Bekasi Jawa Barat.

Berdasarkan hasil pendahuluan diketahui bahwa Santri di Pondok "Y", lebih banyak berjenis kelamin laki-laki, dan berumur antara 16-46 tahun. Namun jumlah individu yang mengalami stres antara laki-laki dan perempuan tidak jauh berbeda. Apabila dilihat dari segi umur, stres dialami oleh berbagai kalangan umur, baik umur remaja sampai dewasa.

Cara individu dalam mensikapi kondisi stres berbeda-beda, tergantung dari pengalaman yang dimiliki, kepribadian, 
dan kondisi lingkungan hidup (Sukadiyanto, 2010). Menurut Hasan (2008), ada tiga hal yang penting yang perlu dilakukan dalam rangka menghadapi stres, yaitu menjalin hubungan baik dengan Allah, pengaturan perilaku, dan mencari dukungan sosial. Islam mengajarkan umatnya mengenai cara menghadapi stress. Islam memandang penting hubungan dengan Allah dalam segala aspek kehidupan manusia. Allah adalah satusatunya dzat yang akan membawa ketenangan sejati dalam diri manusia. Sebagaimana tercantum dalam QS AlRa'ad ayat 28 yang artinya "(yaitu) orangorang yang beriman dan hati mereka menjadi tentram dengan mengingat Allah. Ingatlah, hanya dengan mengingati Allah-lah hati menjadi tenteram".

Selanjutnya, menurut Sukadiyanto (2010), individu yang ingin terhindar dari stres harus selalu mendekatkan diri kepada Allah. Sebaliknya individu yang tidak mengenal dan tidak dekat dengan Allah, maka pendiriannya labil dan mudah goyah. Individu yang dekat dengan Allah akan mempunyai sifat sabar dan tawakal. Sifat sabar, tawakal, dan menerima apa adanya dapat membantu mengurangi stres.

Hasan (2008) menyebutkan bahwa dalam Islam terdapat tiga tata cara yang dapat dilakukan untuk berkomunikasi dengan Allah, salah satunya adalah shalat. Menurut Sukadiyanto (2010), salah satu upaya membangun kedekatan dengan Allah adalah Shalat Tahajud. Shalat tahajud yang dijalankan dengan merasakan dan melakukan cara bernapas yang baik dan benar, maka individu akan terhindar dari stres yang berat. Sholeh (2010) juga menyebutkan bahwa shalat tahajud yang dijalankan dengan penuh kesungguhan, khusyuk, tepat, ikhlas, dan kontinyu dapat menumbuhkan persepsi dan motivasi positif dan mengefektifkan coping. Respons emosi positif (positive thinking), dapat menghindarkan reaksi stres. Dalam hal mengontrol respons emosi, dapat diupayakan dengan beberapa alternatif strategi.

Shalat Tahajud dijalankan pada waktu yang sedikit berbeda dari waktu shalat pada umumnya, yaitu di malam hari setelah melakukan shalat isya serta tidur terlebih dahulu dan waktu yang dianjurkan adalah sepertiga malam terakhir. Sepertiga malam terakhir merupakan waktu di mana individu sedang tidur terlelap. Suasana tenang merupakan kelebihan khusus dari shalat tahajud. Shalat tahajud juga dinamakan shalat lail/shalat malam, karena dilaksanakan pada waktu malam yang sama dengan waktu tidur (Sunusi, 2013).

Allah berfirman pada surah alMuzzammil ayat 6-7, berbunyi: "Sesungguhnya bangun di waktu malam, dia lebih berat dan bacaan di waktu itu lebih berkesan. Sesungguhnya bagimu di siang hari kesibukan yang panjang". Dari ayat tersebut ada dua hal yang dapat diambil pelajaran. Pertama, sengaja untuk bangun malam. Kedua, bacaan di malam hari memiliki efek dan dampak yang lebih mengesankan. Sengaja bangun malam 
hanya bisa dilakukan oleh orang yang memiliki niat kuat.

Dengan penjelasan di atas, hipotesis yang hendak diajukan dalam penelitian ini adalah shalat tahajud efektif dapat menurunkan stres Santri Pondok Islam "Y" Cibarusa Cikarang Bekasi Jawa Barat.

\section{METODE PENELITIAN}

\section{Desain Penelitian}

Desain yang digunakan pada penelitian ini adalah desain eksperimen, dengan menggunakan rancangan eksperimen non randomized pretest posttest control group design.

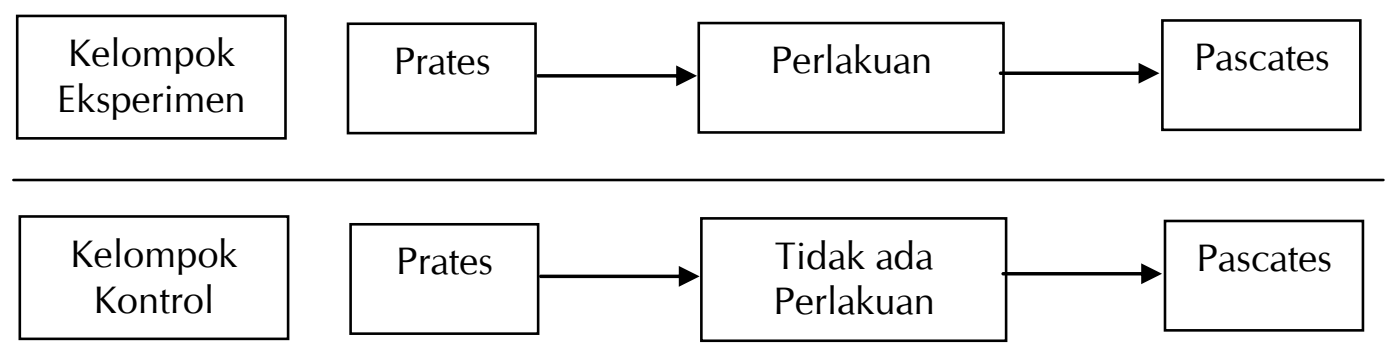

\section{Gambar 1. Desain Penelitian}

\section{Subjek}

Subjek dalam penelitian ini adalah Santri Pondok Islam "Y" Cibarusa Cikarang berjumlah 30 subjek, terdiri atas 2 kelompok. Kelompok 1 adalah kelompok eksperimen dan kelompok 2 adalah kelompok kontrol. Subjek kelompok eksperimen maupun kelompok kontrol belum pernah menjalankan shalat tahajud atau belum rutin menjalankan shalat tahajud berturut-turut selama 10 hari, dan merupakan santri yang baru masuk, dan bersedia atau sanggup menjalankan shalat tahajud secara rutin

\section{Metode Pengumpulan Data}

Metode dalam pengumpulan data adalah menggunakan metode skala. Penyusunan skal ini merujuk kepada konstruk teori stres menurut Sarafino
(2006) di mana stres meliputi dua aspek, yaitu aspek biologis dan aspek psikologis. Skala yang digunakan dalam penelitian ini berjumlah satu skala, yaitu skala stres. Skala tersebut menyediakan empat alternatif jawaban, yaitu $1=$ subjek tidak pernah sama sekali mengalami gejala stres, 2 = jarang atau dalam seminggu 13 kali mengalami gejala stres, $3=$ sering atau dalam seminggu 4-6 kali mengalami gejala stres dan $4=$ selalu atau setiap hari mengalami stres. Pemberian skor pada aitem favorable adalah selalu $=4$, sering $=3$, jarang $=2$, tidak pernah $=1$, sedangkan penilaian terhadap aitem unfavorable adalah selalu $=1$, sering $=$ 2 , jarang $=3$, tidak pernah $=4$.

\section{Intervensi}

Kepada subjek penelitian diberikan 
psikoedukasi tentang shalat tahajud. Selanjutnya mereka mengikuti program shalat tahajud selama 10 malam secara berturut-turut. Mereka selalu dibangunkan pada pukul 03.00 dini hari.

\section{Teknik Analisis Data}

Teknik analisis yang digunakan adalah analisis Paired $t$ test dan Independent $t$ test dengan bantuan komputer (Santoso, 2000).

\section{HASIL PENELITIAN}

\section{Deskripsi Subjek Penelitian}

Pelaksanaan penelitian mendapat hasil penelitian berupa karakteristik subjek penelitian dan hasil analisis. Santri di Pondok Islam " $Y$ " lebih banyak yang berjenis kelamin laki-laki sebesar 60\% daripada yang berjenis kelamin perempuan $(40 \%)$, berumur antara $16-46$ tahun, dan paling banyak berumur dewasa muda (19-40 tahun) sebesar 70\%.

\section{Hasil Analisis Data}

Sebelum menguji kebenaran hipotesis, terlebih dahulu dilakukan uji asumsi, yaitu normalitas. Hasil uji asumsi menunjukkan bahwa semua data berdistribusi normal. Hasil prates dan pascates kelompok eksperimen (paired $t$ test) didapatkan nilai t hitung sebesar 10,821 dengan $p$ sebesar $0,000(p<0,05)$. Hal ini berarti ada penu-runan tingkat stres individu setelah melakukan shalat tahajud dibandingkan dengan sebelum melakukan shalat tahajud. Hasil pengujian pascates antara kelompok eksperimen dan kelompok kontrol (independent $t$ test) didapatkan $t$ hitung sebesar $-5,042$ dengan $p$ sebesar $0,000(p<0,05)$. Hal ini berarti tingkat stres santri yang melakukan shalat tahajud lebih rendah dibandingkan dengan yang tidak melakukan shalat tahajud.

\section{PEMBAHASAN}

Hasil yang diperoleh dari pengujian hipotesis menunjukkan bahwa terdapat perbedaan yang signifikan stres santri sebelum shalat tahajud dan sesudah shalat tahajud ditunjukkan oleh angka $t$ hitung $=10,821$ dengan $\mathrm{p}=0,000(\mathrm{p}<$ $0,05)$. Skor rata-rata stres santri di Pondok Islam " $Y$ " sesudah shalat tahajud $(79,07)$ lebih rendah dibandingkan dengan skor rata-rata stres santri sebelum shalat tahajud $(129,87)$. Hasil uji beda rata-rata stres santri yang melakukan shalat tahajud dengan kelompok yang tidak melakukan tahajud setelah 10 hari berada di pondok, juga menunjukkan hasil yang sangat signifikan (t hitung $=5,042 ; \mathrm{p}=0,000$ ). Rata-rata santri stres santri yang melakukan shalat tahajud jauh lebih rendah $(79,07)$ dengan stres santri yang tidak melakukan shalat tahajud $(100,47)$. Hal ini sesuai dengan hipotesis yang diajukan bahwa ada perbedaan tingkat stres individu sebelum shalat tahajud dan sesudah shalat tahajud. Jadi penelitian ini membuktikan bahwa shalat tahajud dapat menurunkan stres seseorang. 
Hasil penelitian ini ditemukan, stres santri menurun sebagai efek dari menjalankan shalat tahajud yang dilakukan oleh santri selama berada di Pondok"Y". Penurunan tingkat stres santri meliputi dua aspek, yaitu aspek biologis dan aspek psikologis (Sarafino, 2006). Pada kelompok yang menjalankan shalat tahajud, stres santri sebelum masuk ke Pondok Islam"Y" Cibarusa Cikarang pada awalnya tinggi $(40 \%)$, setelah mengikuti kegiatan shalat tahajud yang diadakan oleh Pondok, stres menurun secara signifikan sehingga sebagian besar stres santri rendah $(53,3 \%)$ dan bahkan sangat rendah sebesar $46,7 \%$. Hal ini membuktikan bahwa shalat tahajud mampu menghilangkan perasaan pesimis, rendah diri, minder, kurang berbobot, dan berganti dengan sikap selalu optimis, penuh percaya diri, dan pemberani tanpa disertai sifat sombong dan takabur.

Shalat pada umumnya memberikan pengaruh yang baik terhadap psiko-fisik individu. Dikatakan oleh Ancok dan Suroso (2011) bahwa shalat berfungsi sebagai olahraga. Pada saat shalat berlangsung proses relaksasi. Individu yang melakukannya akan merasakan konstraksi pada ototnya dan tekanan dan massage pada bagian-bagian otot tertentu. Dengan demikian dapat dikatakan bahwa shalat berfungsi memperbaiki kondisi psiko-fisik individu.

Shalat tahajud yang dijalankan santri mampu mengurangi gangguan biologis yang dialami oleh santri. Beberapa gangguan biologis sebagai indikasi stres santri meliputi nyeri otot, penglihatan kabur, jantung berdebar, sesak napas, gangguan lambung, gangguan kandung kemih, muut kering dan kepala terasa berat. Namun setelah menjalankan shalat tahajud, tingkat stres menurun ditandai dengan otototot terasa nyaman, suara stabil, penglihatan jelas, menjadi lebih sehat, jantung berdetak beraturan, dada terasa nyaman dan longgar, nafas teratur, mudah menelan makanan, gangguan di lambung berkurang, mampu menahan air seni serta kepala terasa lebih ringan. Menurut Sholeh (2006), gangguan kesehatan tidak akan timbul jika pengamal shalat tahajud mampu beradaptasi dan berhasil mengupayakan keseimbangan homeostatisnya. Hal ini dikarenakan manusia mempunyai daya kognitif untuk melakukan upaya prevensi supaya tidak merasakan sakit. Upaya prevensi ini di antaranya melalui coping mechanism. Proses terjadinya mekanisme koping ini, diketahui dari upaya penyesuaian diri dan proses belajar dan mengingat. Sebagaimana ditemukan dalam penelitian ini, setelah santri menjalankan shalat tahajud selama 10 hari, merasakan otot-otot yang lebih nyaman walaupun diberi tugas yang menumpuk dari ustad. Dengan demikian, dapat disimpulkan bahwa shalat tahajud dapat menjaga homeostasis tubuh.

Lebih lanjut disebutkan oleh Sholeh (2010), apabila pengamal shalat tahajud mampu beradaptasi dan mempunyai koping yang efektif, perubahan irama sirkadian diterima sebagai stimulator untuk berprestasi. Sebaliknya, jika gagal ber- 
adaptasi dan koping tidak efektif perubahan irama sirkadian akan diterima sebagai stres yang rentan terhadap infeksi dan kanker.

Sholeh (2010) mengemukakan, shalat tahajud yang dijalankan dengan penuh kesungguhan, khusyuk, tepat, ikhlas, dan rutin dapat menumbuhkan persepsi dan motivasi positif dan mengefektifkan koping. Respons emosi positif (positive thinking), dapat menghindarkan reaksi stres. Menurut Taylor, Peplau, dan Sears (2009, berpalingnya individu terhadap agama, yang dalam hal ini individu melakukan shalat tahajud merupakan koping emosi yang efektif. Sebab individu yang menjalankan shalat tahajud akan memperoleh hikmah berupa hidup realistis, selalu optimis dalam kesiapan menghadapi berbagai problema hidup yang dihadapi sehingga orang tetap bersikap konstruktif (Sholeh, 2010). Individu yang melakukan shalat, di antaranya shalat tahajud, akan merasa mempunyai tempat untuk menyandarkan segala urusannya di dunia, yaitu kepada Allah SWT. Individu merasakan ada zat yang dapat membantu meringankan beban hidupnya. Sebagaimana firman Allah SWT yang artinya "Shalatku, ibadahku, hidupku, dan matiku hanya diperuntukkan kepada Allah SWT (QS AIAn'am: 162). Individu merasa bahwa tidak ada satu pun makhluk di muka bumi ini yang bisa menyebabkan mudarat dan menambahkan keuntungan selain izin Allah SWT.
Keyakinan-keyakinan sebagaimana yang diterangkan di atas membantu meningkatkan kemampuan penyesuaian psikologis terhadap kejadian yang menekan yang dialami santri sebelum menjalankan shalat tahajud di Islam "Y". Keyakinan santri setelah menjalankan shalat tahajud meningkat yaitu tumbuhkan sikap optimisme. Shalat tahajud membuat individu merasa dekat dengan Allah SWT. Sebagaimana hadis yang artinya: "Pada tiap malam Tuhan kami Tabaraka wa Ta'ala turun (ke langit dunia) ketika tinggal sepertiga malam yang akhir. la berfirman: "Barang siapa yang menyeru$K u$, akan Aku perkenankan seruannya. Barang siapa yang meminta kepada-Ku, Aku perkenankan permintaanya. Dan barang siapa meminta ampunan kepadaKu, Aku ampuni dia." (HR Bukhari dan Muslim).

Hasil penelitian ini juga membuktikan bahwa individu yang melakukan shalat tahajud lebih banyak yang stresnya menurun dibandingkan dengan individu yang tidak melakukan shalat tahajud. Saat-saat shalat tahajud adalah saat individu sedang dekat-dekatnya dengan Allah. Menjadi pribadi yang dekat dengan Allah tentu akan memberikan manfaat luar biasa bagi kehidupan. Kedekatan dengan Allah akan menjadikan individu lebih optimis sebab doa-doa akan lebih mudah dikabulkan oleh Allah. Kedekatan dengan Allah akan menjadikan individu menjadi pribadi yang berani, karena yakin dengan pertolongan Allah. Kedekatan dengan Allah tidak akan menjadikan 
individu galau, karena selalu ada kejelasan, yaitu mendapatkan ridla Allah. Jadi kedekatan dengan Allah menjadikan individu lebih tegar dalam menghadapi berbagai halangan dan rintangan. Apa pun yang terjadi, individu yakin itulah yang terbaik. Tidak ada yang perlu ditakuti atau dikhawatirkan, semua yang terjadi untuk kebaikan diri sendiri. Individu akan memiliki keyakinan dalam melangkah, sebab langkah individu mendapatkan dukungan dan bimbingan dari Allah (Hawari, 2012).

Menurut Taylor, Peplau, dan Sears (2009), sikap optimisme memampukan individu untuk menilai kejadian yang menekan secara lebih positif dan membantu memobilisasi sumber dayanya untuk mengambil langkah guna menghadapi stressor. Sebagaimana ditemukan pada penelitian ini bahwa stres pada aspek psikologis yang dialami oleh santri juga menurun setelah menjalankan shalat tahajud. Beberapa aspek psikologis yang menurun diantaranya adalah kecemasan berkurang, lebih sabar, rileks, tenang, berani, mudah konsentrasi, menjalankan aktivitas lebih menyenangkan dan perasaan lebih gembira dan mampu menguasai perilaku. Taylor, Peplau dan Sears menambahkan bahwa individu yang tenang dan sabar lebih aktif menjaga kesehatannya dibanding individu yang tidak sabar dan gampang. Jadi santri yang lebih sabar setelah menjalankan shalat tahajud, maka santri akan akan menjaga perilaku dengan tidak memakan makanan yang dapat menimbulkan sakit di lam- bung, santri melakukan aktivitas seperti biasa yaitu istirahat cukup, dan minum secukupnya.

Shalat dapat membuat individu menjadi tegar dan optimis sehingga dapat mengurangi stres. Ketegaran adalah sikapsikap yang membuat orang tahan stres. Sikap ketegaran meliputi perasaan berkomitmen, respon positif terhadap tantangan dan kontrol diri yang kuat. Kontrol diri yang kuat membuat individu mampu menahan efek negatif dari stres (Taylor, Peplau \& Sears (2009). Sebagaimana ditemukan dalam penelitian ini stres santri di Pondok Islam " $Y$ " yang awalnya sangat tinggi sebanyak 12 subjek $(27,3 \%)$, setelah mengamalkan shalat tahajud turun signifikan dan tinggal 1 subjek (2,3\%) stresnya tinggi.

Hasil penelitian ini sejalan dengan teori yang dikemukakan oleh Taylor, Peplau dan Sears (2009), individu yang optimis dapat membantu meningkatkan penyesuaian psikologis terhadap kejadian yang menekan. Optimisme disposisional adalah keyakinan bahwa hasil yang baik akan terjadi dalam kehidupan. Optimisme akan memampukan individu untuk menilai kejadian yang menekan secara lebih positif dan membantu memobilisasi sumber daya internal untuk mengambil langkah guna menghadapi stressor. Orang yang optimis lebih mudah menyesuaikan diri dengan stres dan memiliki tekanan darah yang lebih rendah serta optimisme dapat membantu individu menahan penyakit. 
Individu yang menjalankan shalat tahajud mempunyai kontrol diri yang kuat, lebih tenang dan sabar. Menurut Taylor, Peplau, dan Sears (2009), individu dengan kontrol personal yang tinggi biasanya lebih sukses mengatasi stres, bahkan bisa mengatasi kejadian yang menekan yang sulit dikontrol oleh manusia pada umumnya. Individu yang tenang dan sabar akan lebih aktif untuk menjaga kesehatannya dibandingkan dengan individu yang tidak sabar dan mudah marah.

Penelitian ini tidak luput dari kendala dan keterbatasan. Adapun keterbatasan dalam penelitian ini adalah: (1) jumlah subjek sedikit sehingga tidak bisa dilakukan randomisasi, (2) lokasi penelitian yang jauh, (3) tingkat stres subjek diukur berdasarkan skala bukan berdasarkan hasil tes laboratorium sehingga hasil kurang maksimal, (4) wawancara yang dilakukan kurang mendalam dan menyeluruh sehingga informasi yang didapatkan kurang menggambarkan kondisi yang sesungguhnya, dan (5) peneliti juga tidak melakukan penelitian lebih dalam tentang faktor-faktor yang memengaruhi stres meliputi peristiwa-peristiwa yang menimbulkan stres.

\section{PENUTUP}

\section{Simpulan}

Hasil penelitian menunjukkan bahwa terdapat perbedaan yang signifikan stres santri sebelum shalat tahajud dan sesudah shalat tahajud. Selain itu, terdapat perbedaan yang signifikan stres santri yang melakukan shalat tahajud dan yang tidak melakukan shalat tahajud. Hipotesis pertama yang mengatakan bahwa terdapat perbedaan tingkat stres individu sebelum melakukan shalat tahajud dan sesudah melakukan shalat tahajud terbukti. Hipotesis kedua yang mengatakan bahwa terdapat perbedaan tingkat stres individu yang melakukan shalat tahajud dan yang tidak melakukan shalat tahajud pada Santri Pondok Islam "Y" Cibarusa Cikarang terbukti.

Stres santri di Pondok Islam "Y" sesudah shalat tahajud lebih rendah dibandingkan dengan stres santri sebelum shalat tajahud atau dengan yang tidak melakukan shalat tahajud. Jadi penelitian ini membuktikan bahwa shalat tahajud dapat menurunkan stres seseorang.

\section{Saran}

Saran pertama: Santri disarankan agar mengamalkan shalat tahajud lebih khusuk lagi sehingga didapatkan hasil yang lebih maksimal. Saran kedua: Saran bagi Pondok Islam "Y" Cibarusa Cikarang lebih menciptakan lingkungan yang nyaman dan harmonis sehingga semua warga yang tinggal di dalam Pondok Islam maupun di sekitar pondok dapat hidup sejahtera lahir batin terhindar dari stres. Saran ketiga: untuk peneliti selanjutnya peneliti yang berminat untuk melakukan penelitian tentang stres perlu mempertimbangkan faktor-faktor lain yang turut berpengaruh terhadap stres seperti lingkungan, tipe kepribadian dan emosional. 


\section{DAFTAR PUSTAKA}

Ancok, D. \& Suroso, F.N. (2011). Psikologi Islami: Solusi Islam atas Problem Psikologi. Yogyakarta: Penerbit Pustaka Pelajar.

Baron, R.A. \& Byrne, D. (2010). Psikologi sosial. Jakarta: Penerbit Erlanga.

Ghozali, I. (2007). Aplikasi analisis multivariate dengan program spss. Semarang: Universitas Diponegoro.

Hasan, A.B.P. (2008). Pengantar psikologi kesehatan islami. Jakarta: PT. Raja Grafindo Persada.

Hawari, D. (2012). Ilmu kedokteran jiwa dan kesehatan jiwa perspektif alqur'an dan as-sunnah. Jakarta: Fakultas Kedokteran Universitas Indonesia.
Sarafino, E.P.(2006). Health psychology : biopsychosocial interactions. Second Edition. United States of America: John Wiley \& Sonc, Inc.

Sholeh, M. (2010). Terapi shalat tahajud menyembuhkan berbagai penya-kit. Jakarta: PT Mizan Publika.

Sunusi, D.M., (2013). Indahnya shalat malam : tuntunan qiyamul lail dan shalat tarawih. Makassar: Pustaka as-Sunnah.

Sukadiyanto. (2010). Stres dan cara menguranginya. Jurnal Ilmiah Pendidikan, 29 (1), 45-61.

Taylor, S.E., Peplau, L.A. \& Sears, D.O. (2009). Psikologi sosial. Edisi 12. Alih Bahasa: Wibowo, T. Jakarta : Prenada Media Group. 